\title{
A NOVEL ABA FUNCTIONAL ANALOGUE B2 ENHANCES SALINITY TOLERANCE IN WHEAT
}

\author{
GAber, A. - Feng, T. - WAng, X. - HuAng, G. - Guo, Y. - ZhAng, M. - Li, Z. - Zhou, Y. - \\ DUAN, L. \\ State Key Laboratory of Plant Physiology and Biochemistry, Engineering Research Center of Plant \\ Growth Regulator, Ministry of Education \& College of Agronomy and Biotechnology, China \\ Agricultural University, No. 2 Yuanmingyuan Xi Lu, Haidian District, Beijing 100193, China \\ (e-mails: abeergaber@cau.edu.cn; zhouyuyi711@126.com) \\ *Corresponding author \\ e-mail:duanlsh@cau.edu.cn; phone: +86-186-0127-2095
}

(Received $8^{\text {th }}$ Apr 2020; accepted 29 $9^{\text {th }}$ Jul 2020)

\begin{abstract}
Salinity stress is considered to be the most damaging type of abiotic stress, with devastating effects on wheat production. Abscisic acid (ABA) is a plant hormone that plays an important role in inducing the plant's response to abiotic stresses. Based on the structures of ABA, pyrabactin (PYR) and coronatine (COR), a target chemical compound, B2, was designed in this study. In a previous study, B2 enhanced drought tolerance in wheat by enhancing the ROS capacity, which was achieved by improving the antioxidant enzymes activity and the osmotic adjustment ability. Furthermore, it had a significant effect on improving photosynthesis and increasing the endogenous hormones in wheat under stress conditions. Two wheat cultivars (Triticum aestivum L.), JIMAI22 (JM22) and SHANNONG12 (SH12), were grown under hydroponic conditions to explore the effect of $\mathrm{B} 2$ in mitigating salt stress. The results showed that B2 had a function analogous to ABA, especially at a concentration of $0.1 \mu \mathrm{mol} \cdot \mathrm{L}-1$. Under a salinity stress of $150 \mathrm{mM} \mathrm{NaCl}$, treatment with $0.1 \mu \mathrm{mol} \cdot \mathrm{L}-1 \mathrm{~B} 2$ increased the leaf water content in both wheat cultivars, improving their photosynthetic efficiency and the antioxidant enzyme activity. Moreover, B2 enhanced the expression level of ABA-responsive genes (TaABAOH2, TaNCED1, and TaAREB3). Furthermore, it enhanced the expression level of salt-responsive genes (TaMYB3RI and TaERF3). Moreover, B2 also induced the endogenous plant hormone (ABA) signaling pathway, which led to an improvement of the salt tolerance in the wheat cultivars.
\end{abstract}

Keywords: abscisic acid alternatives, salt stress, ABA and salt-responsive genes, hormonal signaling antioxidant, Triticum aestivum

\section{Introduction}

Wheat is recognized as one of the most commonly cultivated food crops throughout the world and the primary source of proteins and carbohydrates. Current wheat production does not meet the demands of a rapidly growing global population. While plant breeders are working hard to improve wheat production, it is difficult to achieve the required production level due to complex issues, especially abiotic stresses (Jatoi et al., 2011; Moaveni, 2011).

Currently, soil salinity and drought are considered the most damaging abiotic stresses, affecting overall agricultural production. Salinity plays a crucial role in limiting plant production, especially in barren and semi-barren regions (Ashraf et al., 2004; Hussain et al., 2009). The main cause of salt stress in crops could be the use of saline water for irrigation purposes, due to the excessive amount salt in the ground water. Plants have internal mechanisms that help them realize the incoming stresses and regulate their physiological and metabolic processes accordingly to face the calamities (Zhang et al., 2006). 
The plant root system rapidly senses the salt stress, which reduces the plant growth. In the short term, the water availability to the plant is hindered by increasing osmotic stress due to a high salt content, while in the long term, it is hampered by the raised ion toxicity, causing a nutrient deficit in the cytosol (Munns, 2005). A high salt concentration leads to a shortage in plant water uptake, even in well-watered soil, due to a reduction in the osmotic potential of the soil solutes, which makes it difficult for the plant roots to absorb water from the soil solution (Rengasamy, 2006). A high level of salinity also substantially reduces the pigment content of the leaves (Al-Sobhi et al., 2006).

High concentrations of $\mathrm{NaCl}$, such as $125 \mathrm{mM}$ and $150 \mathrm{mM}$, have a completely inhibitory, rather devastating, effect on most of the wheat cultivars (Amor et al., 2005), as most of the growth processes are badly affected. Growth rates and biomass production are efficient indicators to evaluate the level of the stress caused by salt and a plant's ability to resist it (Amor et al., 2005).

The higher salinity concentrations show clear effects on root and shoot lengths, since the roots are directly exposed to salt. A high level of $\mathrm{NaCl}$ causes a reduction in root and shoot development due to its toxic effects and an imbalanced nutrient uptake by plants. It also inhibits root elongation and development by reducing the water uptake by plants.

High salt concentrations decrease the water potential of plants and affect the water availability for the plant physiological functions (Jakab et al., 2005). The osmotic stress, as a result of salt accumulation, leads to a reduction of water absorption through roots and hence creates a water deficit in wheat leaf (Rahnama et al., 2010).

One of the main defense strategies in plants is their antioxidant system. This includes enzymatic and non-enzymatic compounds, which act as detoxification agents, scavenging toxic free radicals and helping the plants overcome destructive oxidative stress (Parida et al., 2004; Li et al., 2011). The major antioxidant defense enzymes are superoxide dismutase (SOD), catalase (CAT) and peroxidase (POD). SOD can scavenge the toxic O2- radicals, and its enzymatic action results in the formation of $\mathrm{H}_{2} \mathrm{O}_{2}$, which is subsequently converted to $\mathrm{H} 2 \mathrm{O}$ by POD (Li et al., 2011).

$\mathrm{ABA}$ is one of the plant hormones that has the ability to regulate the plant physiological responses. It is known as a stress hormone because of its rapid accumulation in response to stresses and its mediation of stress responses, which helps plants to overcome stresses (Zhang et al., 2006). Exogenous ABA application accumulates proline by activating its biosynthesis and inhibiting its degradation pathways, which in turn plays a protective role in salt-stressed plants through scavenging free radicals (Wang et al., 2017). Recent studies show that plant growth responses to abiotic and biotic stresses can be regulated by plant hormones. These hormones have interrelated growth, inducing or inhibiting activities, which leads to a modulation of different plant biosynthesis and physiological responses (Peleg and Blumwald, 2011).

High plants have developed strategies to understand stress signals and modulate the specific stress-responsive gene expressions to acclimate to the stress conditions. Many genes induced by stress have been identified, such as key enzymes of the ABA biosynthesis pathway, osmotic adaptation proteins, cell protective enzymes and transcription factors (TFs). TFs, including AP2/ERF proteins, ABA responsive element (ABRE)-binding proteins and MYB, which play an important role in controlling stressrelated gene expressions. Previous studies declare that different ERF members play various functions in plant responses to abiotic stress (Rong et al., 2014). 
To synthesize the B2 compound, the sub active structure splicing method of integrating ABA, Pyrabactin (PYR), and coronatine (COR) was used, based on the similarities of the amide structure of COR and the sulfonamide-structure of PYR (Zhou et al., 2019) (Fig. Al in the Appendix).

In a previous study, B2 enhanced drought tolerance in wheat by enhancing the ROS capacity, which was achieved by improving the antioxidant enzymes activity and the osmotic adjustment ability. Furthermore, it had a significant effect on improving photosynthesis and increasing the endogenous hormones in wheat under stress conditions (Zhou et al., 2019).

Jimai22 is widely known as salt tolerant genotype (Dugasa et al., 2019) however Shannong 12 was used as test material as it is not investigated for its salinity tolerance previously.

In the present study, the efficiency of compound B2 in enhancing wheat tolerance to salinity stress was investigated. This was because the function of this compound is analogous to that of ABA. The study was conducted to observe the morphological and physiological changes, occurring in different wheat cultivars. Moreover, the variation of the expression level of the related genes, with the use of B2 under high saline conditions, was also investigated.

\section{Materials and methods}

\section{Wheat seedlings preparation and salt stress treatment}

The experiment was conducted in Research Institute China Agricultural University, Beijing, China. Wheat seeds were sterilized by soaking them in $5 \%$ sodium hypochlorite solution for $10 \mathrm{~min}$. The seeds were then washed 3-4 times with distilled water and planted in a plastic net, placed in a hydroponic box. At the one-leaf stage, after germination, the seedlings were transferred into plastic hydroponic boxes, containing Hoagland solution (Hoagland and Arnon, 1950). All the growth-boxes were placed in a greenhouse, set at $22-25^{\circ} \mathrm{C}, 50 \%$ humidity and $14 \mathrm{~h}$ light and $10 \mathrm{~h}$ dark conditions, with a light intensity of $400 \mathrm{~mol} \cdot \mathrm{m}^{2} \cdot \mathrm{s}^{-1}$. Two wheat cultivars, Jimai22 (JM22) and Shannong12 (SH12), were grown to study their performance. After $48 \mathrm{~h}$, when the seedlings were at the two-leaf stage, the chemical compound B2 and ABA treatments were applied by soaking the roots in the treatment solutions for $48 \mathrm{~h}$. The ABA concentration was $0.01 \mu \mathrm{mol} \cdot \mathrm{L}^{-1}$. B2 was added to the concentrations of $0.1 \mu \mathrm{mol} \cdot \mathrm{L}^{-1}, 0.01 \mu \mathrm{mol} \cdot \mathrm{L}^{-1}$ and $0.001 \mu \mathrm{mol} \cdot \mathrm{L}^{-1}$. After the treatment, the seedlings were transplanted into Hoagland nutrient solution. Five days later, seedlings were transplanted into Hoagland nutrient solution, containing $150 \mathrm{mM} \mathrm{NaCl}$ for salt stress treatment. For the purpose of conducting different analyses, leaf samples were taken from the seedlings, including those under the normal conditions (NC) and $\mathrm{NaCl}$ treatments. The treatments were replicated three times, average values of five seedlings were used for each replicate, and samples were collected for physiological measurements or RNA extraction.

\section{Plant growth and biomass accumulation}

For the measurement of fresh weight and dry matter accumulation, shoot, and root were separated and weighed for their fresh weight. The shoot and root dry weight was 
recorded after drying in hot air oven at $65{ }^{\circ} \mathrm{C}$ for $72 \mathrm{~h}$. All the related traits were recorded after eight days of planting.

\section{Root characteristics}

Three plants from each treatment were selected, shoot and roots were separated. The roots of each plant were scanned, (the roots of the same plant were submerged in a water tray to ensure separation of roots and to reduce their overlap, and the roots were scanned by using Epson photo scanner (Epson, Long Beach, CA). Scanned images of roots of respected treatments were analyzed using WinRHIZO Pro image analysis software (Regent Instruments, Inc., Quebec City, QC) to calculate the total root length (sum of the lengths of all roots from the same plant), root volume and total root surface area.

\section{Relative water content $(R W C)$}

Three leaves from each treatment were taken for relative water content (RWC) measurement. The fresh leaf weight $(\mathrm{FW})$ was recorded. The leaves were then dipped in distilled water, for $24 \mathrm{~h}$. The leaves were taken out of the water to record the turgid weight (TW). To record the dry leaf weight (DW), the leaves were dried in an electric oven, set at $65^{\circ} \mathrm{C}$ for $72 \mathrm{~h}$. The relative water content (RWC) of the leaves was calculated as per the formula given by Cornic (1994).

\section{Antioxidant enzymes extraction and assays}

The supernatant, used for the detection of SOD, POD and CAT activities, was according to the protocol described by Parida et al. (2004), where $0.5 \mathrm{~g}$ of leaf tissue was homogenized in $4 \mathrm{~mL}$ of $50 \mathrm{mM}$ sodium phosphate buffer $(\mathrm{pH}=7.0)$, containing $1 \%$ (w/v) PVP, $0.1 \mathrm{mM}$ EDTA-Na2, $1 \mathrm{mM} \cdot \mathrm{L}^{-1}$ iso ascorbic acid and $0.05 \%(\mathrm{w} / \mathrm{v})$ Triton X100 in an ice bath. The homogenate was centrifuged at $12000 \mathrm{rpm}$ and $4{ }^{\circ} \mathrm{C}$ for $15 \mathrm{~min}$.

The soluble proteins content was quantified using the Bradford (1976) method, absorbance values, obtained by a standard curve was prepared with bovine serum albumin.

ABA was extracted and purified using the methods of Bollmark et al. (1988) and Yang et al. (2001) with some modifications. Quantifications were conducted using the ELISA approach. The mouse monoclonal antigens and antibodies, used in ELISA, were produced at the Phytohormones Research Institute China Agricultural University (checked and proven).

\section{Malondialdehyde (MDA) and hydrogen peroxide (H2O2) content}

For the determination of lipid peroxidation in shoots was done by, thiobarbituric acid (TBA) test, which determines Malondialdehyde (MDA) as an end product of lipid peroxidation (Heath and Packer, 1968). Fresh leaf material $(500 \mathrm{mg})$ was homogenized in $5 \mathrm{ml} 0.1 \%(\mathrm{w} / \mathrm{v}) \mathrm{TCA}$ solution. The homogenate was centrifuged at $10000 \times \mathrm{g}$ for $20 \mathrm{~min}$, and $0.75 \mathrm{ml}$ of the supernatant was added to $1.5 \mathrm{ml}$ of $0.5 \%(\mathrm{w} / \mathrm{v})$ TBA in $20 \%$ TCA. The mixture was incubated in boiling water for $30 \mathrm{~min}$, and then reaction stopped by placing the reaction tubes in an ice bath. Then the samples were centrifuged at $10000 \times \mathrm{g}$ for $5 \mathrm{~min}$, and the absorbance of the supernatant was recorded at $532 \mathrm{~nm}$. The value for non-specific absorption at $600 \mathrm{~nm}$ was subtracted. The amount of MDA-TBA complex (red pigment) was calculated from the extinction coefficient $155 \mathrm{mM}^{-1} \mathrm{~cm}^{-1}$. 
$\mathrm{H}_{2} \mathrm{O}_{2}$ levels were determined according to Alexieva et al. (2001). The absorbency of the supernatant was recorded at $390 \mathrm{~nm}$. The content of $\mathrm{H}_{2} \mathrm{O}_{2}$ was given on a standard curve.

\section{Proline content}

Free proline content in shoots of wheat seedling was extracted with $3 \%$ sulfosalicylic acid and centrifuged at $12000 \times \mathrm{g}$. An aliquot was mixed with glacial acetic acid and acidic ninhydrin for $30 \mathrm{~min}$ at $100{ }^{\circ} \mathrm{C}$. The reaction was terminated in an ice bath, and chromophore was extracted with five $\mathrm{mL}$ of toluene. The chromophore-containing toluene was warmed to room temperature, and absorbance was recorded at $520 \mathrm{~nm}$ (Bates et al., 1973).

\section{Determination of photosynthetic parameters}

Photosynthetic speed using a portable photosynthetic apparatus LI-6400 (LI-Cor Inc, Lincoln, NE, USA) to measure the photosynthesis rate, stomatal conductance, intercellular $\mathrm{CO}_{2}$ concentration and transpiration rate. Measurement conditions: leaf surface temperature: $25-28{ }^{\circ} \mathrm{C}$, light intensity $1000 \mu \mathrm{mol} / \mathrm{m}^{2} \mathrm{~s}$, flow rate $500 \mathrm{~mL} / \mathrm{s}$. Each treatment was repeated 3 times, and the newly developed leaves of the seedling leaves were selected at the measurement site.

\section{Statistical analysis}

Two separate experiments were done each one contains one cultivar using complete randomized design (CRD) was used with three replications for each treatment. Analysis of variance (ANOVA) was carried out using Proc Mixed of SAS package version 9.2 (SAS 2008) and means were compared by Duncan's multiple range test at 5\% level of probability (Steel and Torrie, 1980).

\section{Extraction of RNA and quantitative RT-PCR}

Total RNAs were extracted from the leaves using an Easy Pure Plant RNA Kit (Trans Gene Biotech, Beijing). A Nano-Drop2000 spectrophotometer was used to determine the concentrations. Two $\mu \mathrm{g}$ of the total RNA was used to synthesize cDNA, as per the method described in detail by Zhou et al. (2019). Each sample had three independent replicates, and each replicate had three biological repetitions. The $2-\Delta \Delta \mathrm{Ct}$ formula of Livak and Schmittgen (2001) was used to calculate the relative expression level, where reference gene was $\beta$-actin gene (Gene Bank ID: AB181991.1) (Table Al in the Appendix).

\section{Results}

\section{B2 effect on plant growth and biomass accumulation, root characteristics and relative water content $(R W C)$ under salt stress}

Significant differences were found among different treatments, according to statistical analyses, in terms of the plant dry weight and root/shoot ratio of wheat seedlings under salinity stress conditions.

The data regarding the total plant dry weight of seedlings pretreated with B2 showed that cv. JM22 had a $36.8 \%$ increase, and cv. SH12 had a $22.7 \%$ increase, in plant dry 
weight (compared with the control) under salt stress conditions. An increase in the root dry weight was also observed due to the pretreatment of B2. Compared with the control, an increase of $56.7 \%$ and $35.2 \%$ in the root weight was found for cv. JM22 and cv. SH12, respectively, under high saline conditions. Moreover, a significant increase of $20.8 \%$ for cv. JM22 and $14.8 \%$ for cv. SH12, in terms of the root/shoot ratio, was also observed in the seedlings pretreated with $0.1 \mu \mathrm{mol} \cdot \mathrm{L}-1 \mathrm{~B} 2$ under salt stress conditions (Table 1). On the other hand, the lower concentrations of $\mathrm{B} 2$ were not effective under salinity conditions for both wheat cultivars, while the $0.001 \mu \mathrm{mol} \cdot \mathrm{L}-1 \mathrm{~B} 2$ was effective, compared with the control, in cv. JM22 under normal conditions (NC) in terms of the total dry weight and the root dry weight traits.

The data clearly showed that the seedlings treated with ABA or B2, with different concentrations, performed better under salt stress, compared with the untreated ones. It was also observed that $0.1 \mu \mathrm{mol} \cdot \mathrm{L}^{-1} \mathrm{~B} 2$ not only increased the total root length but also enhanced the total root volume and root total surface in JM22 and SH12 (Table 1).

The plant physiological state can be reflected by the relative water content (RWC) of the leaves under salt-stressed conditions. Table 1 shows that the cv. SH12 leaves of seedlings treated with B2 0.1 and $0.001 \mu \mathrm{mol} \cdot \mathrm{L}^{-1}$ had a substantially higher RWC than the control plants, while the cv. JM22 leaves of seedlings treated with B2 0.1, 0.01 and $0.001 \mu \mathrm{mol} \cdot \mathrm{L}^{-1}$ had a significant improvement in RWC under the same concentration of salt. Additionally, ABA-treated seedlings had a significant improvement in both cultivars. ABA and B2 enhanced the RWC of both wheat cultivars, SH12 and JM22, under both saline and non-saline conditions.

Based on the preliminary presented data $0.1 \mu \mathrm{mol} \cdot \mathrm{L}^{-1}$ of $\mathrm{B} 2$ was the best effective concentration among the three investigated concentrations. Therefore, the other two concentrations of B2 were excluded from the following experemints.

\section{Influence of $B 2$ on wheat leaf endogenous ABA level}

Under the salinity stress conditions, the ABA endogenous hormone level increased significantly with $\mathrm{B} 2$ treatment. The $\mathrm{ABA}$ content in leaves, for the treated seedlings (with $0.1 \mu \mathrm{M}$ B2 and ABA), increased, compared with the control, and the endogenous ABA content increased by $88 \%$ and $22 \%$ in JM 22 , respectively, and increased by $106 \%$ and $76 \%$ in SH12, respectively (Fig. 1).

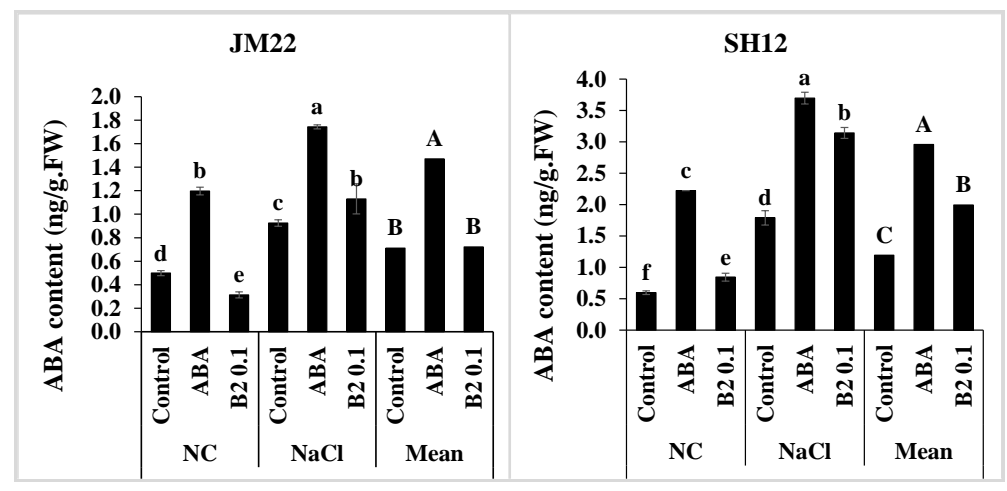

Figure 1. Effect of $B 2$ on the content of endogenous hormone ABA in both wheat cultivars Jimai22 and Shannong12. Normal conditions $(\mathrm{NC})$, under salt stress $(\mathrm{NaCl})$ and the mean of each treatment under both conditions (Mean). The data are expressed as the mean $\pm S E$ of three replicates. Means are compared using Duncan's test at 5\% level of significant. Bars labeled with same letters are not significantly differ from each other 
Table 1. Effect of B2 on Plant growth and biomass accumulation, root characteristics and relative water content $(R W C)$ in both wheat cultivars Jimai22 and Shannong 12. Normal conditions $(\mathrm{NC})$ and under salt stress $(\mathrm{NaCl})$. The data are expressed as the mean $\pm S E$ of three replicates. Means are compared using Duncan's test at $5 \%$ level of significant. Values labeled with same letters are not significantly differ from each other

\begin{tabular}{|c|c|c|c|c|c|c|c|c|c|}
\hline \multicolumn{3}{|c|}{ Treatment } & \multirow{2}{*}{$\begin{array}{c}\begin{array}{c}\text { Plant dry } \\
\text { weight } \\
\text { (mg/plant) }\end{array} \\
421.8^{\mathrm{c}}\end{array}$} & \multirow{2}{*}{$\begin{array}{c}\begin{array}{c}\text { Root dry } \\
\text { weight } \\
\text { (mg/plant) }\end{array} \\
118.5^{\mathrm{d}}\end{array}$} & \multirow{2}{*}{$\begin{array}{c}\begin{array}{c}\text { Root/shoot } \\
\text { ratio }\end{array} \\
0.39^{\mathrm{b}}\end{array}$} & \multirow{2}{*}{\begin{tabular}{|c}
$\begin{array}{c}\text { Total root } \\
\text { length }(\mathbf{c m})\end{array}$ \\
$2087.8^{\mathrm{d}}$
\end{tabular}} & \multirow{2}{*}{$\begin{array}{c}\begin{array}{c}\text { Root } \\
\text { surface } \\
\left(\mathbf{c m}^{2}\right)\end{array} \\
189.3^{\mathrm{e}}\end{array}$} & \multirow{2}{*}{$\begin{array}{c}\begin{array}{c}\text { Root } \\
\text { volume } \\
\left(\mathbf{c m}^{\mathbf{3}}\right)\end{array} \\
1.4^{\mathrm{f}}\end{array}$} & \multirow{2}{*}{$\begin{array}{r}\text { RWC \% } \\
90.0^{\mathrm{b}}\end{array}$} \\
\hline \multirow{15}{*}{ 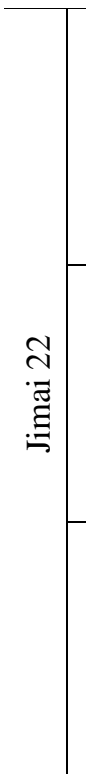 } & \multirow{10}{*}{$\begin{array}{l}\bar{\Xi} \\
\text { Z }\end{array}$} & Control & & & & & & & \\
\hline & & $\mathrm{ABA}$ & $553.3^{\mathrm{a}}$ & $165.8^{\mathrm{a}}$ & $0.43^{\mathrm{a}}$ & $2268.7^{c}$ & $213.5^{\mathrm{d}}$ & $1.7^{\mathrm{de}}$ & $93.3^{\mathrm{a}}$ \\
\hline & & B2 0.1 & $495.8^{a b}$ & $148.2^{b}$ & $0.43^{\mathrm{a}}$ & $2487.9^{\mathrm{b}}$ & $249.5^{b}$ & $1.9^{\mathrm{c}}$ & $91.7^{\mathrm{ab}}$ \\
\hline & & B2 0.01 & $338.8^{\mathrm{d}}$ & $98.7^{\mathrm{e}}$ & $0.4^{\mathrm{ab}}$ & $1901.1^{\text {ef }}$ & $231.3^{\mathrm{c}}$ & $2.3^{\mathrm{a}}$ & $92.8^{\mathrm{ab}}$ \\
\hline & & B2 0.001 & $510.2^{\mathrm{a}}$ & $144.8^{\mathrm{b}}$ & $0.4^{\mathrm{ab}}$ & $2988.0^{\mathrm{a}}$ & $284.0^{\mathrm{a}}$ & $2.2^{\mathrm{b}}$ & $92.2^{\mathrm{a}}$ \\
\hline & & Control & $315.7^{\mathrm{d}}$ & $82.7^{\mathrm{f}}$ & $0.4^{c}$ & $1136.1^{\mathrm{g}}$ & $121.0^{\mathrm{f}}$ & $1.1^{\mathrm{g}}$ & $81.0^{\mathrm{d}}$ \\
\hline & & $\mathrm{ABA}$ & $444.7^{b c}$ & $132.2^{\mathrm{c}}$ & $0.4^{\mathrm{a}}$ & $2051.0^{\text {de }}$ & $203.8^{\text {de }}$ & $1.6^{\mathrm{e}}$ & $82.6^{\mathrm{cd}}$ \\
\hline & & B2 0.1 & $432.0^{c}$ & $129.5^{\mathrm{c}}$ & $0.4^{\mathrm{a}}$ & 2007.0 de & $205.1^{\mathrm{de}}$ & $1.7^{\mathrm{de}}$ & $83.7^{c}$ \\
\hline & & B2 0.01 & $314.7^{\mathrm{d}}$ & $90.5^{\mathrm{ef}}$ & $0.4^{\mathrm{ab}}$ & 1939.9 def & $208.0^{\mathrm{d}}$ & $1.8^{\mathrm{d}}$ & $84.1^{\mathrm{c}}$ \\
\hline & & B2 0.001 & $331.8^{\mathrm{d}}$ & $96.2^{\mathrm{e}}$ & $0.4^{\mathrm{ab}}$ & $1815.2^{\mathrm{f}}$ & $203.1^{\mathrm{de}}$ & $1.8^{\mathrm{de}}$ & $83.4^{\mathrm{c}}$ \\
\hline & \multirow{5}{*}{$\stackrel{\Xi \Xi}{\Sigma}$} & Control & & $100.6^{\mathrm{D}}$ & $0.37^{\mathrm{C}}$ & $1611.9^{\mathrm{D}}$ & $155.2^{\mathrm{D}}$ & $1.2^{\mathrm{E}}$ & $85.5^{\text {B }}$ \\
\hline & & $\mathrm{ABA}$ & $499.0^{\mathrm{A}}$ & $149.0^{\mathrm{A}}$ & $0.43^{\mathrm{A}}$ & $2159.9^{\text {B }}$ & $208.6^{\mathrm{C}}$ & $1.7^{\mathrm{D}}$ & $87.9^{\mathrm{A}}$ \\
\hline & & B2 0.1 & $463.9^{\mathrm{A}}$ & $138.8^{\text {В }}$ & $0.43^{\mathrm{A}}$ & $2247.5^{\text {B }}$ & $227.3^{\mathrm{B}}$ & $1.8^{\mathrm{C}}$ & $87.7^{\mathrm{A}}$ \\
\hline & & B2 0.01 & $326.8^{\text {B }}$ & $94.6^{\mathrm{D}}$ & $0.40^{\mathrm{B}}$ & $1920.5^{\mathrm{C}}$ & $219.6^{\text {B }}$ & $2.1^{\mathrm{A}}$ & $88.5^{\mathrm{A}}$ \\
\hline & & B2 0.001 & $421.0^{\mathrm{D}}$ & $120.5^{\mathrm{C}}$ & $0.40^{\mathrm{B}}$ & $2401.6^{\mathrm{A}}$ & $243.5^{\mathrm{A}}$ & $2.0^{\mathrm{B}}$ & $87.8^{\mathrm{A}}$ \\
\hline \multirow{15}{*}{ 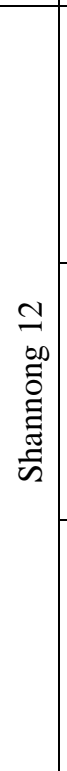 } & \multirow{10}{*}{$\begin{array}{l}\vec{U} \\
\bar{z}\end{array}$} & Control & $326.7^{b}$ & $95.2^{\mathrm{c}}$ & $0.41^{\mathrm{cd}}$ & $854.7^{\mathrm{d}}$ & $101.3^{\mathrm{d}}$ & $1.0^{\mathrm{c}}$ & $89.3^{b}$ \\
\hline & & $\mathrm{ABA}$ & & $132.0^{\mathrm{a}}$ & $0.46^{\mathrm{a}}$ & $1971.3^{\mathrm{a}}$ & $193.8^{\mathrm{a}}$ & $1.6^{\mathrm{a}}$ & $92.0^{\mathrm{a}}$ \\
\hline & & B2 0.1 & $357.5^{\mathrm{b}}$ & $109.0^{\mathrm{b}}$ & $0.44^{\mathrm{ab}}$ & $1057.3^{c}$ & $116.9^{c}$ & $1.0^{\mathrm{c}}$ & $92.0^{\mathrm{a}}$ \\
\hline & & B2 0.01 & & $104.0^{\mathrm{bc}}$ & $0.42^{\mathrm{bc}}$ & $1542.8^{\mathrm{b}}$ & $149.0^{\mathrm{b}}$ & $1.2^{\mathrm{b}}$ & $92.4^{\mathrm{a}}$ \\
\hline & & B2 0.001 & $284.8^{\mathrm{c}}$ & $61.5^{\mathrm{e}}$ & $0.28^{\mathrm{e}}$ & $563.9^{\mathrm{e}}$ & $60.1^{\mathrm{g}}$ & $0.5^{f}$ & $91.9^{\mathrm{a}}$ \\
\hline & & Control & $263.3^{\mathrm{cd}}$ & $74.8^{\mathrm{d}}$ & $0.40^{\text {cd }}$ & $385.5^{f}$ & $50.2^{g}$ & $0.5^{\mathrm{f}}$ & $83.6^{\mathrm{cd}}$ \\
\hline & & $\mathrm{ABA}$ & $325.3^{\mathrm{b}}$ & $101.7^{b c}$ & $0.45^{\mathrm{a}}$ & $845.3^{\mathrm{d}}$ & $87.9^{\mathrm{e}}$ & $0.7^{\mathrm{d}}$ & $88.3^{b}$ \\
\hline & & B2 0.1 & $323.2^{b}$ & $101.2^{b c}$ & $0.46^{\mathrm{a}}$ & $788.3^{d}$ & 77.5 ef & $0.6^{\text {ef }}$ & $85.3^{c}$ \\
\hline & & B2 0.01 & $247.0^{\mathrm{d}}$ & $70.3^{\mathrm{d}}$ & $0.40^{\mathrm{cd}}$ & $633.5^{\mathrm{e}}$ & $73.6^{f}$ & $0.7^{\mathrm{de}}$ & $81.5^{\mathrm{d}}$ \\
\hline & & B2 0.001 & $207.3^{\mathrm{e}}$ & $58.3^{\mathrm{e}}$ & $0.39^{\mathrm{d}}$ & $837.3^{\mathrm{d}}$ & $109.7^{\mathrm{cd}}$ & $1.2^{\mathrm{b}}$ & $85.2^{\mathrm{c}}$ \\
\hline & \multirow{5}{*}{$\sum_{\Sigma}^{\tilde{\Xi}}$} & Control & $295.0^{\mathrm{C}}$ & $85.0^{\mathrm{C}}$ & $0.40^{\mathrm{B}}$ & $620.1^{\mathrm{E}}$ & $75.7^{\mathrm{E}}$ & $0.7^{\mathrm{D}}$ & $86.4^{\mathrm{C}}$ \\
\hline & & $\mathrm{ABA}$ & $371.3^{\mathrm{A}}$ & $116.8^{\mathrm{A}}$ & $0.46^{\mathrm{A}}$ & $1408.3^{\mathrm{A}}$ & $140.8^{\mathrm{A}}$ & $1.1^{\mathrm{A}}$ & $90.1^{\mathrm{A}}$ \\
\hline & & B2 0.1 & $340.2^{\text {B }}$ & $105.1^{\mathrm{B}}$ & $0.45^{\mathrm{A}}$ & $922.8^{\mathrm{C}}$ & $97.2^{\mathrm{C}}$ & $0.8^{\mathrm{C}}$ & $88.7^{\mathrm{AB}}$ \\
\hline & & B2 0.01 & $298.8^{\mathrm{C}}$ & $87.2^{\mathrm{C}}$ & $0.41^{\mathrm{B}}$ & $1088.2^{\text {B }}$ & $111.3^{\mathrm{B}}$ & $0.9^{\text {в }}$ & $86.9^{\mathrm{C}}$ \\
\hline & & B2 0.001 & $246.1^{\mathrm{D}}$ & $59.9^{\mathrm{D}}$ & $0.33^{\mathrm{C}}$ & $700.1^{\mathrm{D}}$ & $84.9^{\mathrm{D}}$ & $0.8^{\mathrm{C}}$ & $88.5^{\text {в }}$ \\
\hline
\end{tabular}

\section{B2 effect on the wheat leaves soluble protein content under high salinity levels}

After going through the salt stress, the recorded plant content of soluble protein was higher in B2- and ABA-treated leaves, compared with the control. It increased significantly, by $17 \%$ in cv. JM22 and $31 \%$ in cv. SH12 B2-treated seedlings, in comparison with the control seedlings, while it increased by 9 and 15\% in JM22 and SH12, respectively, in ABA-treated seedlings (Fig. 2). Pre-treatment with both 
$0.1 \mu \mathrm{mol} \cdot \mathrm{L}^{-1} \mathrm{~B} 2$ and ABA efficiently enhanced the wheat leaf content of soluble protein under high saline conditions.
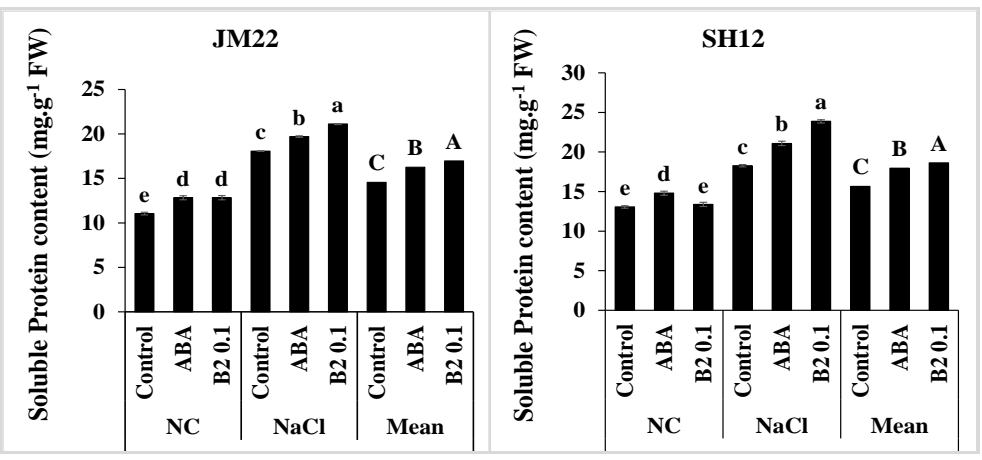

Figure 2. Effect of B2 on the soluble protein content in both wheat cultivars Jimai22 and Shannong 12. Normal conditions $(\mathrm{NC})$, under salt stress $(\mathrm{NaCl})$ and the mean of each treatment under both conditions (Mean). The data are expressed as the mean $\pm S E$ of three replicates. Means are compared using Duncan's test at 5\% level of significant. Bars labeled with same letters are not significantly differ from each other

\section{B2 influence on the antioxidant enzymes activity under saline conditions}

Three days after the salt application, the antioxidant enzyme activity was analyzed. The antioxidant activity of CAT, SOD and POD enzymes was obviously affected by salt stress. The SOD activity significantly increased due to B2 in the leaves of both wheat cultivars. The rate of increase was 17 and $18 \%$ for cv. JM22 and cv. SH12, respectively. Furthermore, there was a significant enhancement in the POD activity, where the rate of increase reached $16 \%$ in cv. JM22 and 23\% in cv. SH12. Additionally, the antioxidant enzyme CAT activity increased significantly in both cv. JM22 and cv. SH12, at 15 and $10 \%$, respectively. In addition, ABA significantly enhanced the antioxidant enzyme activity of SOD, POD and CAT in both cultivars, JM22 and SH12, and the rates of increase were 23 and $16 \%$ for the SOD activity, 17 and $8 \%$ for the POD activity and 34 and $30 \%$ for the CAT activity, respectively, compared with the untreated seedlings under the saline condition (Fig. $3 a, b, c)$.

\section{Proline content}

After application of salt stress, it was notable that the plant content of proline become higher in leaves. It increased significantly by $14 \%$ and $15 \%$ in JM22 and SH12 treated seedlings with B2 and $19 \%$ and $26 \%$ with ABA compared with the non-treated seedlings in the same concentration of salt (Fig. 4). Pre-treatment with both $0.1 \mu \mathrm{mol} \cdot \mathrm{L}^{-1} \mathrm{~B} 2$ and ABA could efficiency enhance leaves content of proline in both cultivars of wheat crop under the high-level salt conditions.

\section{Lipid peroxidation and ROS accumulation}

Under salt stress conditions, data clearly presented that $\mathrm{ABA}$ and the chemical compound B2 have improving effect on MDA in both wheat cultivars JM22 and SH12, both treatments successfully decreased the MDA level by $16 \%$ and $33 \%$ with ABA treatment and $14 \%$ and $30 \%$ with B2 treatment in both JM22 and SH12 respectively (Fig. 5a). 


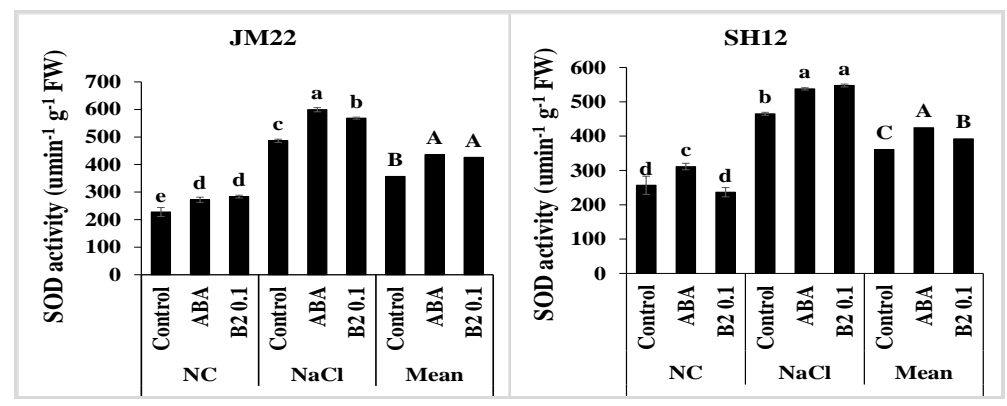

(a)

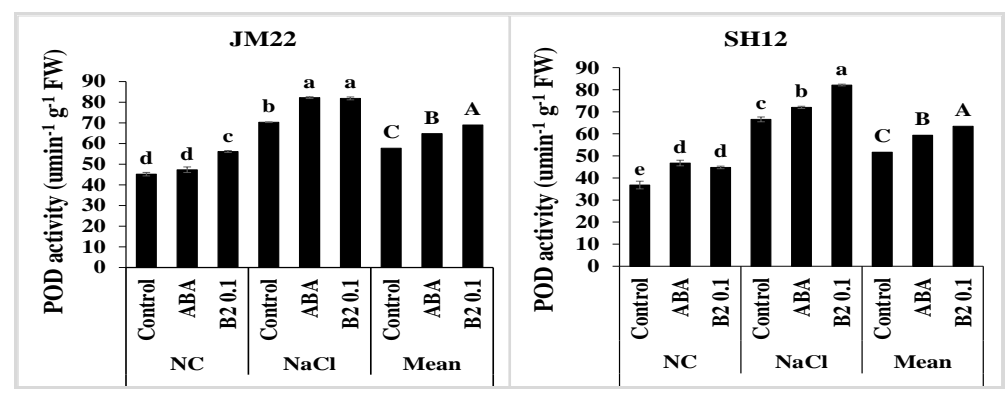

(b)

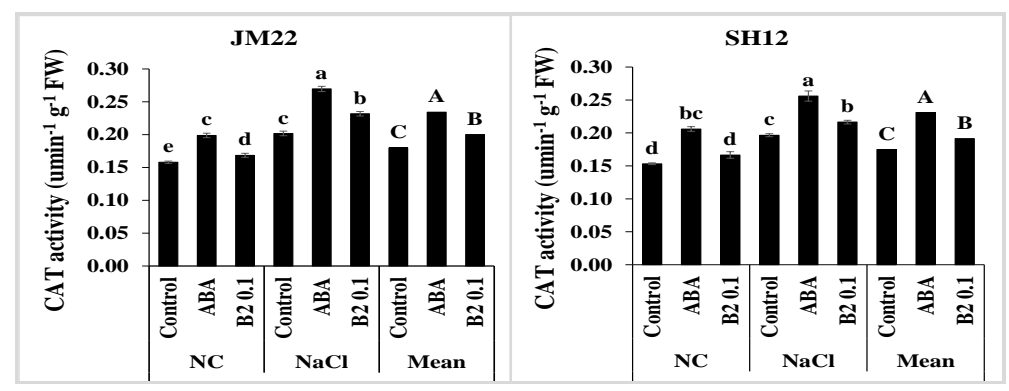

(c)

Figure 3. Effect of $B 2$ on the antioxidant enzyme activity. (a) Superoxide dismutase (SOD). (b) Peroxidase (POD). (c) Catalase (CAT) in both wheat cultivars Jimai22 and Shannong 12. Normal conditions $(\mathrm{NC})$, under salt stress $(\mathrm{NaCl})$ and the mean of each treatment under both conditions (Mean). The data are expressed as the mean $\pm S E$ of three replicates. Means are compared using Duncan's test at 5\% level of significant. Bars labeled with same letters are not significantly differ from each other
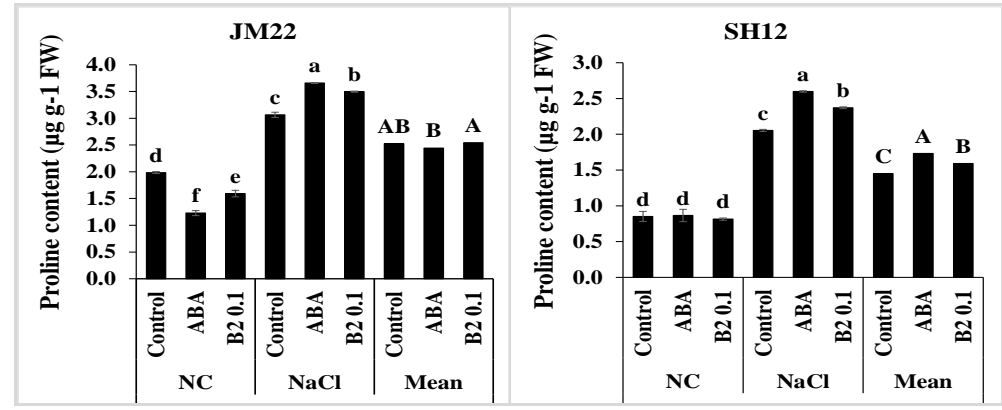

Figure 4. Effect of B2 on proline content in both wheat cultivars Jimai22 and Shannong12. Normal conditions $(\mathrm{NC})$, under salt stress $(\mathrm{NaCl})$ and the mean of each treatment under both conditions (Mean). The data are expressed as the mean $\pm S E$ of three replicates. Means are compared using Duncan's test at 5\% level of significant. Bars labeled with same letters are not significantly differ from each other 
Both ABA and B2 treatments had significantly showed lower accumulation of $\mathrm{H}_{2} \mathrm{O}_{2}$ in salt conditions. Where, $\mathrm{ABA}$ and $\mathrm{B} 2$ reduced the level of $\mathrm{H}_{2} \mathrm{O}_{2}$ in both wheat cultivars leaves, the decreasing rate were $29 \%$ and $44 \%$ with $\mathrm{ABA}$ and $32 \%$ and $71 \%$ with B2 in JM22 and SN12 respectively (Fig. 5b).

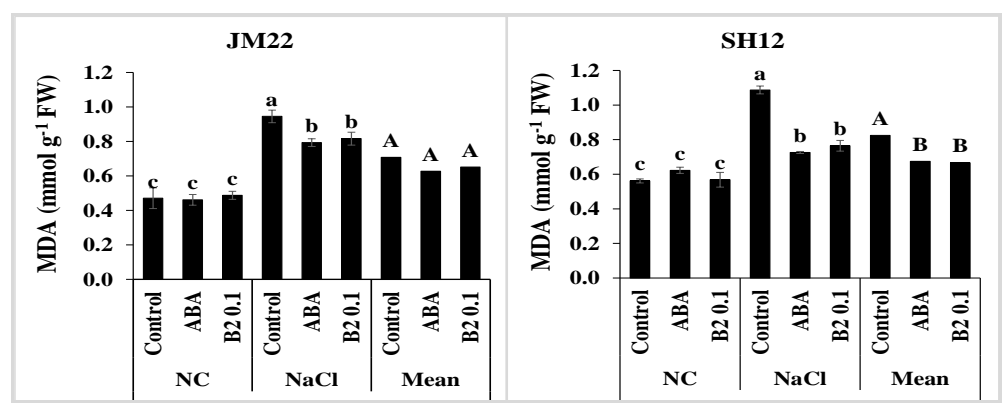

(a)

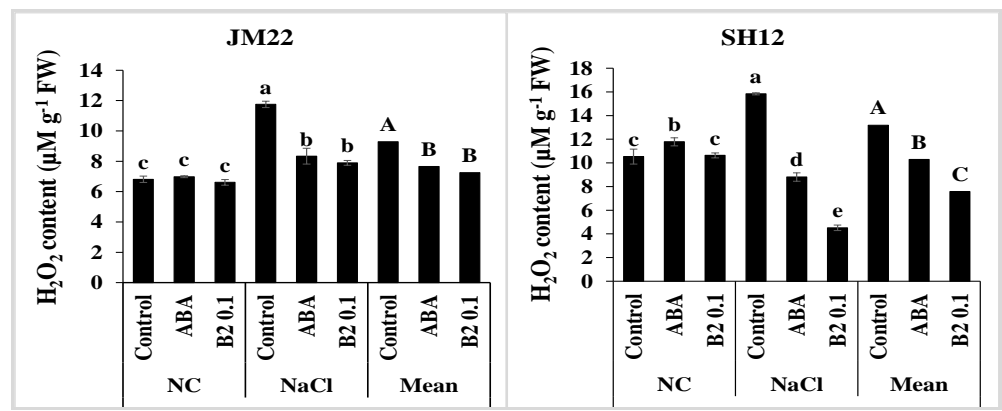

(b)

Figure 5. Effect of $\mathrm{B} 2$ on $\mathrm{MDA}(\mathrm{a})$ and $\mathrm{H}_{2} \mathrm{O}_{2}(b)$ content in both wheat cultivars Jimai22 and Shannong 12. Normal conditions $(\mathrm{NC})$, under salt stress $(\mathrm{NaCl})$ and the mean of each treatment under both conditions (Mean). The data are expressed as the mean \pm SE of three replicates. Means are compared using Duncan's test at $5 \%$ level of significant. Bars labeled with same letters are not significantly differ from each other

\section{Effect of B2 on wheat leaf photosynthetic rate under salinity stress}

The data showed that seedlings treated with ABA or B2 had a high photosynthesis rate, as compared with the control treatment, while growing under salt stress conditions. The photosynthesis rate of ABA- and B2-pretreated seedlings increased by 43 and $39 \%$ in cv. JM22 and by 37 and $28 \%$ in cv. SH12, respectively, compared with the non-treated seedlings under a high salinity. Additionally, there was a notable effect of ABA and B2 on wheat leaf stomatal conductance and transpiration rate under salt stress in both the cultivars. Moreover, there was a significant increase in B2-treated seedlings in both indicators, Stomatal conductance $(\mathrm{Sc})$ and Transpiration rate $(\mathrm{Tr})$, in the wheat cultivar, SH12, under salt stress conditions, and it increased by 84 and $68 \%$, respectively, while the effect was not notable in JM22 under the stress conditions. On the other hand, the increase rate was not significant for ABA-treated seedlings in both indicators, Stomatal conductance (Sc) and Transpiration rate (Tr), in both SH12 and JM22 (Fig. 6a, b, c).

\section{Effect of $A B A$ and $B 2$ on the expression of salt and $A B A$-responsive genes}

With the B2 and ABA pre-treatment of wheat seedlings, the expression level of saltresponsive genes (i.e., TaERF3 and TaMYB3Rl), along with the ABA-responsive genes 
(i.e., TaABAOH2, TaNCED1, and TaAREB3), increased significantly under salt stress. However, the time for each gene to reach the highest expression level was different, depending on the treatment and cultivar. The expression level of TaERF3 increased with $\mathrm{B} 2$ and ABA treatments, compared with the control, under salt stress, based on time. Here, B2 was comparable with ABA in terms of the increase in the expression level of the mentioned gene. In cv. JM22, B2 increased TaERF3 expression at 12, 24, 48 and $72 \mathrm{~h}$, and its effect was higher than that of ABA from 24 to $72 \mathrm{~h}$ (Fig. $7 a, b)$. However, in cv. SH12, the significant increase started at $6 \mathrm{~h}$ for the treatment with both B2 and ABA (Fig. 7d). On the other hand, an initial increase in the expression level of TaMYB3Rl was seen in cv. JM22 at $3 \mathrm{~h}$ due to ABA treatment. However, the expression dropped down with time (Fig. 7c). In the case of cv. SH12, TaMYB3R1 expression increased linearly at 24, 48 and $72 \mathrm{~h}$ due to the effect of B2, unlike the nonlinear influence of ABA (Fig. $7 d$ ). Under salt stress, B2 improved the expression level of TaABAOH2 in cv. JM22 and cv. SH12, especially at 72 and $24 \mathrm{~h}$, respectively (Fig. 8e,f). Furthermore, like ABA, B2 enhanced the expression level of TaNCED1 in $\mathrm{cv}$. JM22 at $72 \mathrm{~h}$ and significantly enhanced the expression of the same gene in $\mathrm{cv}$. SH12 at $24 \mathrm{~h}($ Fig. $7 g, h)$. The effect of B2 and ABA was almost similar on the expression of TaAREB3 in cv. JM22, which reached its peak at $72 \mathrm{~h}$. However, in $\mathrm{cv}$. SH12, only ABA affected the gene expression at $12 \mathrm{~h}$, with no significant effect of B2, compared with the control (Fig. 7i,j).

\section{Discussion}

Soil salinity and drought are considered to be the most damaging abiotic stresses affecting agricultural production. It has previously been reported that ABA affects plant growth and development and has a role in plant responses to abiotic stresses, including salt, cold and drought stresses (Zhu, 2002).

Under saline conditions, applying a proper concentration of ABA enhances the salinity tolerance and increases the growth rate in sorghum and rice crops (Gurmani and Bano, 2007). Shoot fresh and dry weight decreases with an increase in salinity, but the application of ABA decreases the inhibitory effect of salt on shoot weight to some extent. The root weight of wheat also increases, if the seed is pretreated with ABA (Gurmani and Bano, 2007). These previous studies are in accordance with the present study. Here, both the treatments of $\mathrm{ABA}$ and $\mathrm{B} 2$ enhanced the total dry weight, root/shoot ratio, and root growth rate.

The plant physiological state is reflected by the relative water content (RWC) of its leaves. The reduction of the leaf water potential (LWP) and relative water content (RWC) were significantly moderated by ABA treatment under saline conditions. Additionally, ABA priming enhanced the RWC and LWP of salt-acclimated plants under subsequent salt stress. This indicates that ABA helps in maintaining a better water status of wheat plants under salinity stress (Davies and Zhang, 1991). The positive effect of ABA-induced antioxidant activity and the reduction in oxidative stress was further manifested by an increase in RWC, plant growth and membrane stability index (Gong and $\mathrm{Li}, 1998$ ).

In this study, both $\mathrm{B} 2$ and ABA promoted the RWC of both wheat cultivars. In accordance with these observations. B2 enhanced the root growth, and plant total fresh and dry weight, leading to an improved water absorption capacity of wheat seedlings and hence an improved RWC (Karcher et al., 2008). 


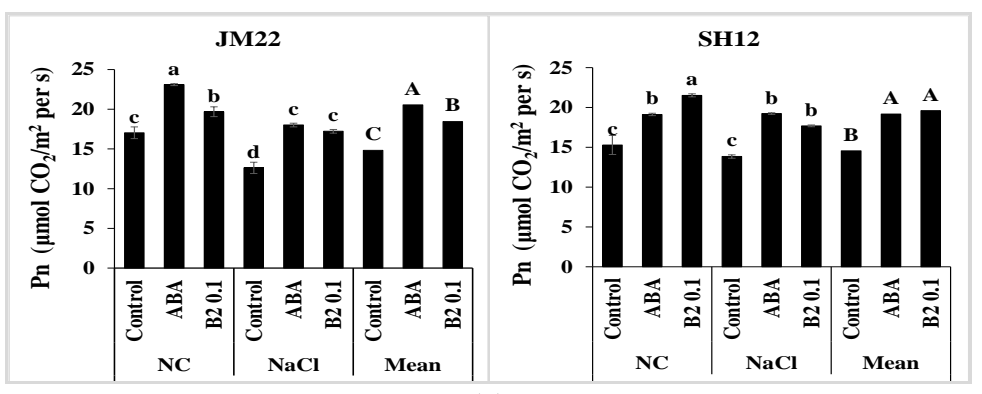

(a)

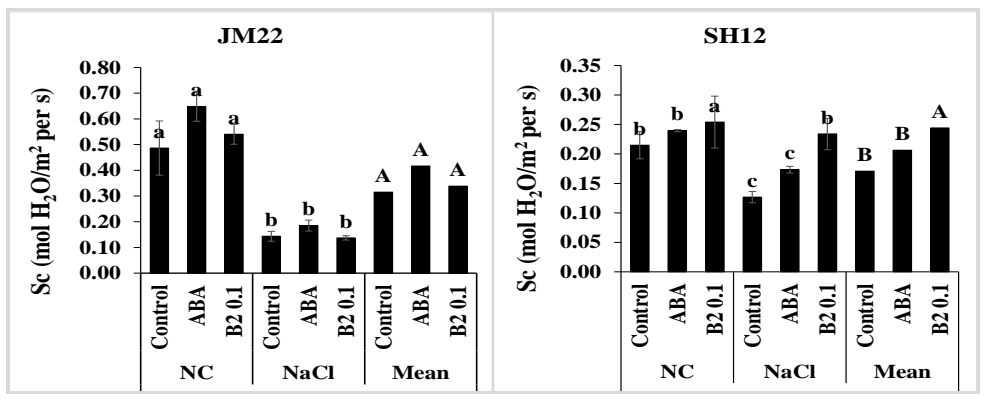

(b)

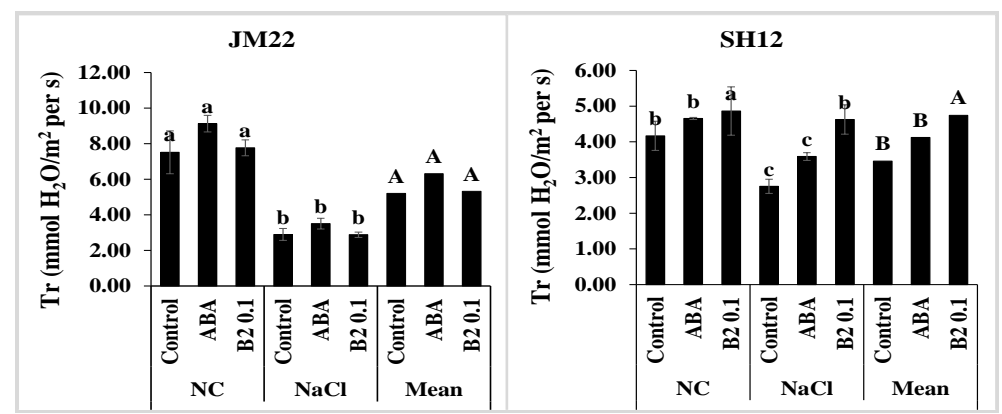

(c)

Figure 6. Effect of B2 on the (a) Photosynthesis rate (Pn) (b) Stomatal conductance (Sc). (c) Transpiration rate (Tr) in both wheat cultivars Jimai22 and Shannong12. Normal conditions $(\mathrm{NC})$, under salt stress $(\mathrm{NaCl})$ and the mean of each treatment under both conditions (mean).

The data are expressed as the mean $\pm S E$ of three replicates. Means are compared using Duncan's test at $5 \%$ level of significant. Bars labeled with same letters are not significantly differ from each other

ABA accumulation in plant cell decreased the level of $\mathrm{Na}^{+}$, regardless of whether these plants were salt acclimated. The endogenous ABA content notably increased with the salt treatment. A reduced $\mathrm{Na}^{+}$concentration and increased $\mathrm{ABA}$ level were caused by the combination of salt acclimation and ABA priming. ABA wheat plant priming improves the endogenous ABA content, which leads to a reduction in $\mathrm{Na}^{+}$uptake and accumulation (Davies and Zhang, 1991).

In the present study, the endogenous $\mathrm{ABA}$ level increased under salinity conditions. This indicates that B2 induced ABA accumulation in wheat plants. It also contributes to antioxidant enzyme's resisting system regulation and osmotic stress adjustment and enhancement, thus reducing oxidative damage.

One of the main defense strategies in plants is their antioxidant system. This includes enzymatic and non-enzymatic compounds, which act as detoxification agents of toxicfree radicals and therefore help the plant to overcome the destructive oxidative process 
(Li et al., 2011; Zhang et al., 2016). The major antioxidant defense enzymes are SOD, CAT, and POD. POD decomposes $\mathrm{H}_{2} \mathrm{O}_{2}$ through the oxidation of co-substrates, such as phenolic compounds and/or other antioxidants, whereas CAT breaks down $\mathrm{H}_{2} \mathrm{O}_{2}$ into $\mathrm{H} 2 \mathrm{O}$ and $\mathrm{O} 2$ (Mittler, 2002; Li et al., 2011). An increase in SOD activity decreases free radicals, especially superoxide radicals that harm cell membranes, increase plant tolerance to oxidative stress and scavenges $\mathrm{O}_{2}{ }^{-}$radicals (Manjili et al., 2012).

Many studies indicate that the antioxidant system has a critical role in plant resistance to oxidative damage caused by salinity stress (Mittler, 2002; Xie et al., 2008; Qiu et al., 2014). Therefore, improving the antioxidant enzyme activities in plants results in an enhancement of the plant tolerance to salt stress. ABA has a positive effect in inducing the POD, SOD, and CAT activity in wheat plants exposed to a high salt stress (Davies and Zhang, 1991). ABA has a positive effect on adaptation responses in wheat (Agarwal et al., 2005).

The present results show that $\mathrm{B} 2$ mimics $\mathrm{ABA}$ and can enhance the scavenging capacity of reactive oxygen species (ROS) by improving the antioxidant enzymatic activities in wheat seedlings under saline conditions. Therefore, B2 could diminish the oxidative damage, which was also confirmed by the improvement in the soluble protein level, SOD, POD, and CAT, which led to the enhancement in the osmotic adjustment potential of the wheat seedlings.

Plants show many physiological and biochemical responses to cope the environmental abiotic stresses such as the accumulation of proline (Delauney and Verma,1993). In fact, free proline accumulates in a wide variety of higher plants, such as tobacco, soybean, barley, wheat and rice (Yoshiba et al.,1999). Proline play a major role in free radical scavenging, adjusting cell osmotic and a compatible solute that protects enzymes (Verbruggen et al., 1993). The metabolism of proline is essential for the plant stress resistance (Hare et al.,1999). Furthermore, it has been confirmed that accumulation of proline in cells improve osmotic and salt stress tolerance in transgenic plants (Kavi-Kishor et al., 1995; Zhu, 2002), although there also existed the regards that proline was an alternative result from adaptive or detrimental processes responding to osmotic stress (Larher et al., 2003). Proline also has a main function as protecting the enzymes from dehydration and salt accumulation (Thomas, 1990), and because of increasing abscisic acid concentration in response to various stresses (Unyayar et al., 2004), it seems that abscisic acid spraying increases proline content as a defense mechanism. ABA increased the proline content of flag leaf in the high salt level conditions (Flower and Yeo, 1989).

One of the ABA functions is enabling the plant to rapidly respond to salt stress by inducing stomatal closure. This is achieved through the modulation of the cytosolic CA2 ${ }^{+}$ concentration, which leads to the depolarization of the guard cell, as a result of an improved ABA level (Wang et al., 2017). It has been proved that salt causes the inhibition of photosynthesis, which could be due to stomatal or non-stomatal limitations. Gas stomata conductance (gs) decreases significantly due to salt stress, while ABA application improves the gs level in wheat plants under saline conditions (Davies and Zhang, 1991).

ABA has a photosynthesis regulation function in wheat plants adapted to salt through the regulation of non-stomatal parameters. ABA plays an effective role in the plant's resistance to salt stress by decreasing the water loss and adjusting the osmotic stress through stomatal control. ABA priming treatment improved the carbon absorbance and water use efficiency of the adapted wheat plants under salt stress (Davies and Zhang, 1991). 

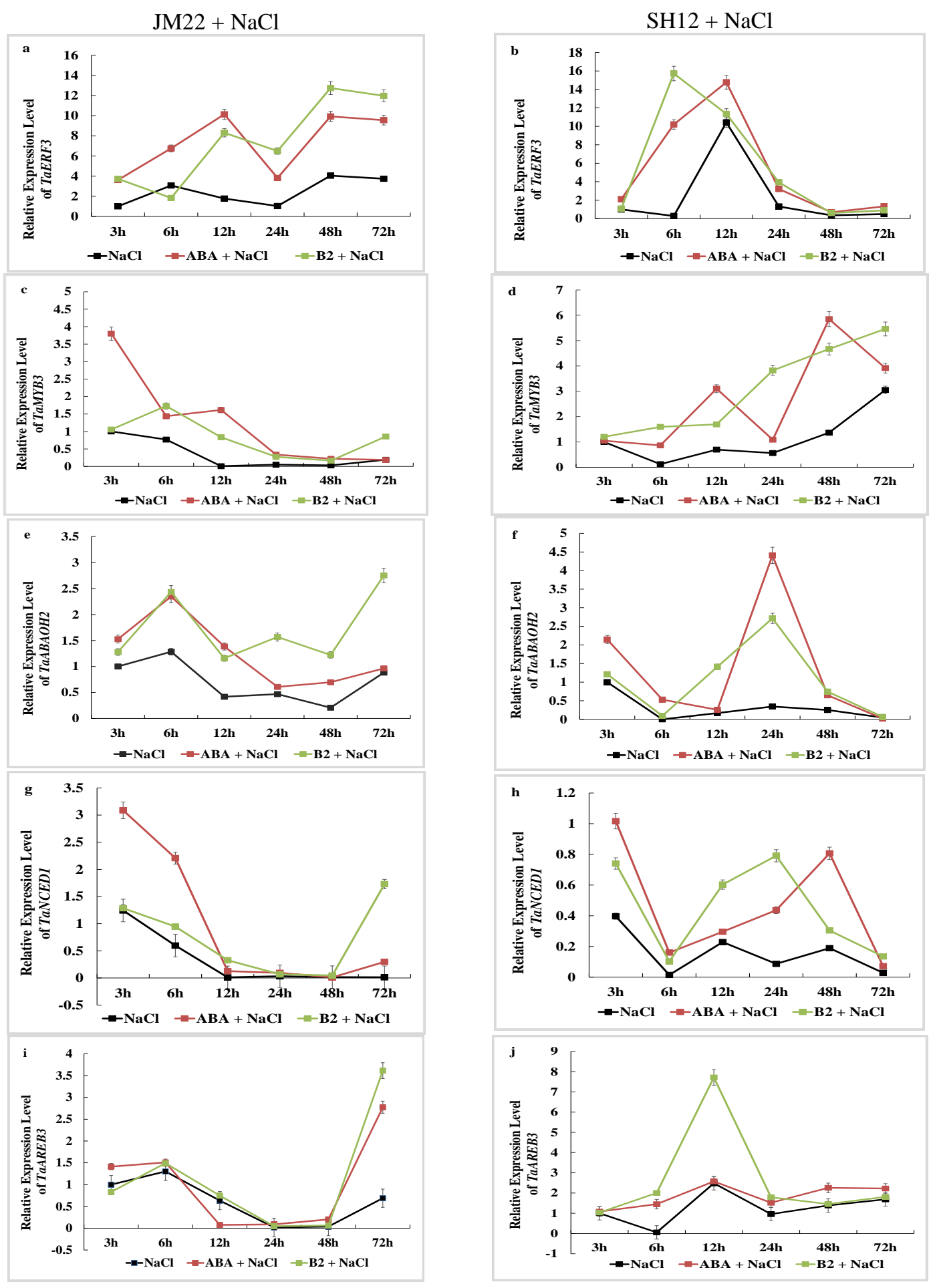

Figure 7. Expression of salt- and ABA-responsive genes in wheat seedlings at $3 h, 6 h, 12 h$, $24 \mathrm{~h}, 48 \mathrm{~h}$, and $72 \mathrm{~h}$ under salt stress conditions. Control under salt conditions ( $\mathrm{NaCl}$ ); $\mathrm{ABA}$ treatment of wheat seedlings under salt conditions $(A B A+N a C l) ; B 2$ treatment of wheat seedlings under salt conditions $(\mathrm{B2}+\mathrm{NaCl})$. (a) TaERF3 gene expression level in JM22, (b) TaERF3 gene expression level in SH12, (c) TaMYB3R1 gene expression level in JM22, (d) TaMYB3R1 gene expression level in SH12, (e) TaABAOH2 gene expression level in JM22, ( $f$ ) TaABAOH2 gene expression level in SH12, $(g)$ TaNCED1 gene expression level in JM22, $(h)$ TaNCED1 gene expression level in SH12, (i) TaAREB3 gene expression level in JM22, and (j) TaAREB3 gene expression level in SH12 
It is well known that the salt-induced inhibition of photosynthesis is attributed to stomatal and non-stomatal limitations (Wang et al., 2017). It might be that ABA improves the photosynthesis of wheat plants under salt stress due to the regulation of some other non-stomatal parameters. Nevertheless, stomatal control by ABA appears to be an efficient strategy for decreasing water loss and the negative effects of osmotic stress, caused by salinity (Wang et al., 2017).

A comparison of the influence of both $\mathrm{ABA}$ and $\mathrm{B} 2$ analogues on the expression of some genes related to salt stress and the ABA response was also performed. The effect of $\mathrm{B} 2$ on the expressions of these genes was found to be similar and sometimes superior to that of $\mathrm{ABA}$, which reflected its efficiency as a stress regulator. However, the activation of gene expression was mainly based on the gene, time, and cultivar. The results showed that $\mathrm{B} 2$, like $\mathrm{ABA}$, simulated the expression level of all the studied genes. In addition, among the tested genes, some were involved in drought and salt stress, such as transcription factor TaERF3 (Zhang et al., 2007a), which was previously isolated and characterized in wheat. This transcription factor may directly regulate the expressions of different stress-related genes by interacting either with their promoters or with other TFs (Buttner and Singh, 1997; Zhang et al., 2007b). Additionally, TaERF3 may indirectly regulate the expression of other stress-related genes involved in proline and chlorophyll accumulation, redox homeostasis $\left(\mathrm{H}_{2} \mathrm{O}_{2}\right.$ reduction), and stomatal closure, which consequently become the induction of abiotic stress tolerance (Rong et al., 2014). It is well known that ERF proteins possess a vital role in regulating the expression of specific stress-related genes. Moreover, ERF subfamily members were primarily involved in biotic stresses as well (Berrocal et al., 2002; Onate et al., 2007; Chen et al., 2008). On the other hand, recent studies show that ERF members are also involved in diverse functions in plant responses to abiotic and biotic stresses (Rong et al., 2014). MYB proteins play multifunctional roles in the regulation of gene expressions (Rosinski and Atchley, 1998; Jin and Martin, 1999). For instance, they control the cell shape and morphogenesis involvement in abiotic and biotic stress responses to ABA (Cai et al., 2011). The TaMYB3Rl gene expression was up-regulated, and its expression remained high under both cold and salt stresses. This suggested that TaMYB3R1 may take part in abiotic stress regulation in wheat. In the present study, the TaMYB3R1 gene was affected by ABA and B2, based on the time and plant genotype. However, B2 was more efficient than $\mathrm{ABA}$ in enhancing the gene expression in $\mathrm{cv}$. SH12 in a linear mode through time. This result proved that the novel analogue (B2) has a good influence in enhancing stress tolerance in wheat.

\section{Conclusions}

From this study, it is apparent that $\mathrm{B} 2$ and $\mathrm{ABA}$ have a similar performance in improving the active oxygen radical scavenging efficiency by improving the antioxidant enzyme activity and enhancing the osmotic adjustment ability in wheat under salt stress. Moreover, the photosynthesis rate and the plant endogenous ABA content also increased, which confirms that B2 has a special regulating physiological mechanism. Suggestion that the findings could be beneficial in eradicating the salt stress problem in agricultural field crops is premature. Further studies should be performed to explain the effect of B2 on other crop plants such as rice since it considered as the main food crop in China, and investigate the effect of B2 based on the molecular analysis. 
Acknowledgements. We thank Prof. Yan Guo in College of Biological Science, CAU for providing technical assistance. This research was funded by The National Key Research and Development Program of China (2016YFD0300102-4) and the National Science Fund for Distinguished Young Scholars (31425017) supported this study.

\section{REFERENCES}

[1] Agarwal, S., Sairam, R. K., Srivastava, G. C., Meena, R. C. (2005): Changes in antioxidant enzymes activity and oxidative stress by abscisic acid and salicylic acid in wheat genotypes. - Biologia Plantarum 49: 541-550.

[2] Alexieva, V., Sergiev, I., Mapelli, S., Karanov, E. (2001): The effect of drought and ultraviolet radiation on growth and stress markers in pea and wheat. - Plant, Cell and Environment 24(12): 1337-1344.

[3] Al-Sobhi, O. A., Al-Zaharani, H. S., Al-Ahmadi, S. B. (2006): Effect of salinity on chlorophyll and carbohydrate contents of Calotropis procera seedlings. - Scientific Journal of King Faisal University 7: 105-114.

[4] Amor, N. B., Hamed, K. B., Debez, A., Grignon, C., Abdelly, C. (2005): Physiological and antioxidant responses of perennial halophyte Crithmum maritimum to salinity. Plant Science 4: 889-899.

[5] Ashraf, M., Harris, J. C. (2004): Potential biochemical indicators of salinity tolerance in plants. - Plant Science 166: 3-16.

[6] Bates, L. S., Waldren, R. P., Teare, I. D. (1973): Rapid determination of free proline for water-stress studies. - Plant and Soil 39(1): 205-207.

[7] Berrocal-Lobo, M., Molina, A., Solano, R. (2002): Constitutive expression of ETHYLENE-RESPONSE-FACTOR 1 in Arabidopsis confers resistance to several necrotrophic fungi. - Plant Journal 29: 23-32.

[8] Bollmark, M., Kubat, B., Eliasson, L. (1988): Variations in endogenous cytokinin content during adventitious root formation in pea cuttings. - Journal of Plant Physiology 132: 262-265.

[9] Bradford, M. M. (1976): A rapid and sensitive method for the quantitation of microgram quantities of protein utilizing the principle of protein-dye binding. - Analytical Biochemistry 72: 248-254.

[10] Buttner, M., Singh, K. B. (1997): Arabidopsis thaliana ethylene-responsive element binding protein (AtEBP), an ethylene-inducible, GCC box DNA-binding protein interacts with an ocs element binding protein. - Proceedings of the National Academy of Sciences of the United States of America 94: 5961-5966.

[11] Cai, H., Tian, S., Liu, C., Dong, H. (2011): Identification of an MYB3R gene involved in drought, salt and cold stress in wheat (Triticum aestivum L.). - Gene 485: 146-152.

[12] Chen, L., Zhang, Z., Liang, H., Liu, H., Du, L., Xu, H., Xin, Z. (2008): Overexpression of TiERF1 enhances resistance to sharp eyespot in transgenic wheat. - Journal of Experimental Botany 59: 4195-4204.

[13] Cornic, G. (1994): Drought Stress and High Light Effects on Leaf Photosynthesis. - In: Baker, N. B., Bowyer, J. R. (eds.) Photo-Inhibition of Photosynthesis. BIOS Scientific Publishing, Oxford.

[14] Davies, W. J., Zhang, J. (1991): Root signals and the regulation of growth and development of plants in drying soil. - Annual Review of Plant Physiology and Plant Molecular Biology 42: 55-76.

[15] Delauney, A. J., Verma, D. P. S. (1993): Proline biosynthesis and osmoregulation in plants. - Plant Journal 4: 215-223.

[16] Dugasa, M. T., Cao, F., Ibrahim, W., Wu, F. (2019): Differences in physiological and biochemical characteristics in response to single and combined drought and salinity 
stresses between wheat genotypes differing in salt tolerance. - Physiologia Plantarum 165: 134-143.

[17] Flower, T. J., Yeo, A. R. (1989): Effects of Salinity on Plant Growth and Crop Yield. In: Cherry, J. (ed.) Environmental Stress in Plants. Biochemical and Physiological Mechanisms. Springer, Berlin.

[18] Gong, M., Li, Y. J., Chen, S. Z. (1998): Abscisic acid induced thermos tolerance in maize seedlings is mediated by $\mathrm{Ca}^{+}$and associated with antioxidant systems. - Plant Physiology 153: 488-496.

[19] Gurmani, A. R., Bano, A., Salim, M. (2007): Effect of Abscisic acid and Benzyl adenine on growth and ion accumulation of wheat under salinity stress. - Pakistan Journal of Botany 39(1): 141-149.

[20] Hare, P. D., Cress, W. A., van Staden, J. (1999): Proline synthesis and degradation: a model system for elucidating stress related signal transduction. - Journal of Experimental Botany 50: 413-434.

[21] Heath, R. L., Packer, L. (1968): Photoperoxidearion in isolated chloroplasts. I. Kinetics and stoichiometry of fatty acid peroxidation. - Archives of Biochemistry and Biophysics 125: 189-198.

[22] Hoagland, D. R., Arnon, D. I. (1950): The Water Culture Method for Growing Plant without Soil. - University of California Press, Berkley, CA.

[23] Hussain, K., Majeed, A., Nawaz, K., Khizar, H. B., Nisar, M. F. (2009): Effect of different levels of salinity on growth and ion contents of black seeds (Nigella sativa L.). Current Research Journal of Biological Sciences 1: 135-138.

[24] Jakab, G., Ton, J., Flors, V., Zimmerli, L., Me'traux, J. P., Mauch-Mani, B. (2005): Enhancing Arabidopsis salt and drought stress tolerance by chemical priming for its abscisic acid responses. - Journal of Plant Physiology 139: 267-274.

[25] Jatoi, W. A., Baloch, M. J., Kumbhar, M. B., Khan, N. U., Kerio, M. I. (2011): Effect of water stress on physiological and yield parameters at anthesis stages in elite spring wheat cultivars. - Sarhad Journal of Agriculture 27: 59-65.

[26] Jin, H., Martin, C. (1999): Multifunctionality and diversity within the plant MYB-gene family. - Plant Molecular Biology 41: 577-585.

[27] Karcher, D. E., Richardson, M. D., Hignight, K., Rush, D. (2008): Drought tolerance of tall fescue populations selected for high root/shoot ratios and summer survival. - Crop Science 48: 771-777.

[28] Kavi-Kishor, P. B., Hong, Z., Miao, G. H., Hu, C., Verma, D. P. S. (1995): Overexpression of [delta]-pyrolline-5-carboxylate synthetase increases proline production and confers osmotolerance in transgenic plants. - Plant Physiology 108: 1387-1394.

[29] Larher, F. R., Aziz, A., Gibon, Y., Trotel-Aziz, P., Sulpice, R., Bouchereau, A. (2003): An assessment of the physiological properties of the so-called compatible solutes using in vitro experiments with leaf discs. - Plant Physiology and Biochemistry 41: 657-666.

[30] Li, J. T., Qiu, Z. B., Zhang, X. W., Wang, L. S. (2011): Exogenous hydrogen peroxide can enhance tolerance of wheat seedlings to salt stress. - Acta Physiologiae Plantarum 33: 835-842.

[31] Livak, K. J., Schmittgen, T. D. (2001): Analysis of relative gene expression data using real-time quantitative PCR and the 2- $\Delta \Delta \mathrm{CT}$ method. - Methods 25: 402-408.

[32] Manjili, F. A., Sedghi, M., Pessarakli, M. (2012): Effect of phytohormones on proline content and antioxidant enzymes of various wheat cultivars under salinity stress. Journal of Plant Nutrition 35: 1098-1111.

[33] Mittler, R. (2002): Oxidative stress, antioxidants and stress tolerance. - Trends in Plant Science 7: 405-410.

[34] Moaveni, P. (2011): Effect of water deficit stress on some physiological traits of wheat (Triticum aestivum). - Agricultural Science Research Journal 1: 64-68.

[35] Munns, R. (2005): Genes and salt tolerance: bringing them together. - Plant Physiology 167: 645-663. 
[36] Onate-Sanchez, L., Anderson, J. P., Young, J., Singh, K. B. (2007): AtERF14, a member of the ERF family of transcription factors, plays a nonredundant role in plant defense. Plant Physiology 143: 400-409.

[37] Parida, A. K., Das, A. B., Mohanty, P. (2004): Defense potentials to $\mathrm{NaCl}$ in a mangrove, Bruguiera parviflora: differential changes of isoforms of some antioxidative enzymes. Plant Physiology 161: 531-542.

[38] Peleg, Z., Blumwald, E. (2011): Hormone balance and abiotic stress tolerance in crop plants. - Current Opinion in Plant Biology 14: 290-295.

[39] Qiu, Z., Guo, J., Zhu, A., Zhang, L., Zhang, M. (2014): Exogenous jasmonic acid can enhance tolerance of wheat seedlings to salt stress. - Ecotoxicology and Environmental Safety 104: 202-208.

[40] Rahnama, A., James, R. A., Poustini, K., Munns, R. (2010): Stomatal conductance as a screen for osmotic stress tolerance in durum wheat growing in saline soil. - Functional Plant Biology 37: 255-263.

[41] Rengasamy, P. (2006): World salinization with emphasis on Australia. - Journal of Experimental Botany 57: 1017-1023.

[42] Rong, W., Qi, L., Wang, A., Ye, X., Du, L., Liang, H., Xin, Z., Zhang, Z. (2014): The ERF transcription factor TaERF3 promotes tolerance to salt and drought stresses in wheat. - Plant Biotechnology Journal 12: 468-479.

[43] Rosinski, J. A., Atchley, W. R. (1998): Molecular evolution of the Myb family of transcription factors: evidence for polyphyletic origin. - Journal of Molecular Evolution 46: 74-83.

[44] SAS Institute (2008): The SAS System for Windows, release 9.2. - SAS Institute, Cary, NC.

[45] Steel, R. G., Torrie, J. (1980): Principles and Procedures of Statistics - A Biological Approach. 2nd Ed. - Mc. Graw-Hill Book Co. Inc, New York.

[46] Thomas, H. (1990): Osmotic adjustment in Lolium perenne; its heritability and the nature of solute accumulation. - Annals of Botany 66: 521-530.

[47] Unyayar, S., Keles, Y., Unal, E. (2004): Proline and ABA levels in two sunflower genotypes subjected to water stress. - Bulgarian Journal of Plant Physiology 30: 34-47.

[48] Verbruggen, N., Villarroel, R., van Montagu, M. (1993): Osmoregulation of a pyrroline5-carboxylate reductase gene in Arabidopsis thaliana. - Plant Physiology 103: 771-781.

[49] Wang, Z. S., Li, X. N., Zhu, X. C., Liu, S. Q., Song, F. B., Liu, F. L., Wang, Y., Qi, X. N., Wang, F. H., Zuo, Z. Y., Duan, P. Z., Yang, A. Z., Cai, J., Jiang, D. (2017): Salt acclimation induced salt tolerance is enhanced by abscisic acid priming in wheat. - Plant, Soil and Environment 63: 307-314.

[50] Xie, Z. X., Duan, L. S., Tian, X. L., Wang, B. M., Eneji, A. E., Li, Z. H. (2008): Coronatine alleviates salinity stress in cotton by improving the antioxidative defense system and radical-scavenging activity. - Journal of Plant Physiology 165: 375-384.

[51] Yang, J., Zhang, J., Wang, Z., Zhu, Q., Wang, W. (2001): Hormonal changes in the grains of rice subjected to water stress during grainfilling. - Plant Physiology 127: 315323.

[52] Yoshiba, Y., Nanjo, T., Miura, S., Yamaguchi-Shinozaki, K., Shinozaki, K. (1999): Stress-responsive and developmental regulation of $\Delta 1$-pyrroline-5-carboxylate synthetase 1 (P5CS1) gene expression in Arabidopsis thaliana. - Biochemical and Biophysical Research Communications 261: 766-772.

[53] Zhang, H., Li, W., Chen, J., Yang, Y., Zhang, Z., Wang, X. C., Huang, R. (2007b): Transcriptional activator TSRF1 reversely regulates pathogen resistance and osmotic stress tolerance in tobacco. - Plant Molecular Biology 55: 825-834.

[54] Zhang, J., Jia, W., Yang, J., Ismail, M. A. (2006): Role of ABA in integrating plant responses to drought and salt stresses. - Field Crop Research 97: 111-119.

[55] Zhang, J., Yu, H., Zhang, Y., Wang, Y., Li, M., Zhang, J., Duan, L., Zhang, M., Li, Z. (2016): Increased abscisic acid levels in transgenic maize overexpressing AtLOS5 
mediated root ion fluxes and leaf water status under salt stress. - Journal of Experimental Botany 67: 1339-1355.

[56] Zhang, Z., Yao, W., Dong, N., Liang, H., Liu, H., Huang, R. (2007a): A novel ERF transcription activator in wheat and its induction kinetics after pathogen and hormone treatments. - Journal of Experimental Botany 58: 2993-3003.

[57] Zhou, Y., He, R., Guo, Y., Liu, K., Huang, G., Peng, C., Liu, Y., Zhang, M., Li, Z., Duan, L. (2019): A novel ABA functional analogue B2 enhances drought tolerance in wheat. Science Reports 9: 2887-2895.

[58] Zhu, J. K. (2002): Salt and drought stress signal transduction in plants. - Annual Review of Plant Biology 53: 247-273.

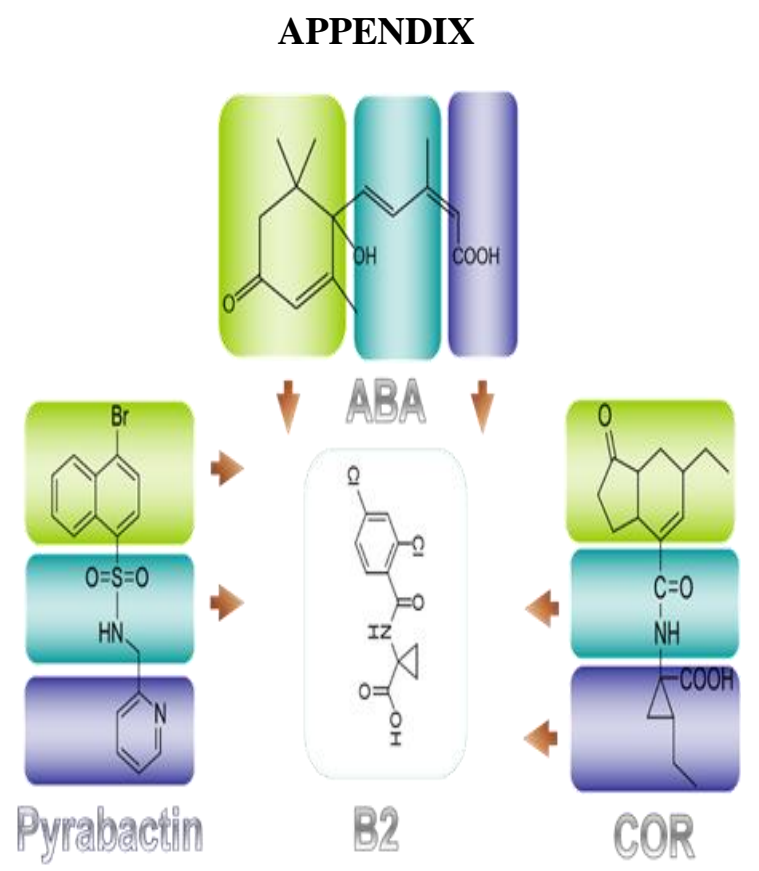

Figure A1. The synthesis process of B2. We adopted sub active structure splicing method, integrating ABA, Pyrabactin and Coronatine, and then synthesized compound B2

Table A1. Sequences of primers used in this study

\begin{tabular}{c|c|c}
\hline Gene name & Primer & Sequence (5'-3') \\
\hline \multirow{2}{*}{ Actin } & $\mathrm{F}$ & GACCCAGACAACTCGCAACT \\
\cline { 2 - 3 } & $\mathrm{R}$ & CTCGCATATGTGGCTCTTGA \\
\hline \multirow{2}{*}{$T a N C E D 1$} & $\mathrm{~F}$ & CGACGGGTACATTCTCACCT \\
\cline { 2 - 3 } & $\mathrm{R}$ & CCTGAGATTCGAGCTCCTTG \\
\hline \multirow{2}{*}{$T a A B A O H 2$} & $\mathrm{~F}$ & TACAGGTGGGAGGTTGTTGG \\
\cline { 2 - 3 } & $\mathrm{R}$ & TCGTAGTCGTCATCAGTCGG \\
\hline \multirow{2}{*}{$T a A R E B 3$} & $\mathrm{~F}$ & CTCAAGGACACGAGCGATGCTG \\
\cline { 2 - 3 }$T a M Y B 3 R 1$ & $\mathrm{R}$ & CATTCAGCGGCTGAGGGACAAAC \\
\cline { 2 - 3 } & $\mathrm{F}$ & ACGAGAAAGACCGACACCTGC \\
\hline \multirow{2}{*}{$T a E R F 3$} & $\mathrm{R}$ & AACCCAGTGACAGAAAGGAAGCA \\
\cline { 2 - 3 } & $\mathrm{R}$ & AGCAATCAGGCAAAGCAACC \\
\hline
\end{tabular}

